\title{
Diabetes Mellitus Type II: Treatment Strategies and Options: A Review \\ Muhammad Akram*
}

Department of Eastern Medicine and Surgery, Faculty of Medical and Health Sciences, The University of Poonch, Pakistan

\begin{abstract}
Traditional medicines are practiced worldwide for treatment of type II diabetes mellitus since ancient times. This review provides a comprehensive summary of medicinal plant throughout the world regarding their traditional usage by various tribes/ethnic groups for treatment of type II diabetes mellitus. Various treatment options are available in allopathic system of medicine. The prevalence of type II diabetes mellitus is increasing in all over the world. The need for achieving better control of blood glucose level has been evident in type II diabetes mellitus management. A wide number of herbal products are employed in the treatment of type II diabetes mellitus for their better efficacy and safety compared to synthetic medicine. Objective of study is to review conventional and herbal treatment of type II diabetes mellitus and document the medicinal plants used for treatment of type II diabetes mellitus that will help the physician in their practice. The material for this review was taken mostly from endocrinology textbooks \& electronic journal Up to date. To collect publication Pub Med, Google scholars and the Cochrane database of systematic reviews was used. Some other relevant references were collected from personal database of papers on type II diabetes mellitus. World health organization (WHO) is also supporting the research on herbal medicine regarding type II diabetes mellitus. Various hypoglycemic agents from medicinal plants have been found that are effective and safe. The medicinal plants used for the treatment of type II diabetes mellitus were reviewed based on the ethno botanic, some chemical and biochemical reports. Various plants species belonging to different families have been documented used for treatment of type II diabetes mellitus.
\end{abstract}

Keywords: Type II diabetes mellitus; Medicinal plants; Efficacy; Herbal medicine; Literature review

\section{Introduction}

Type II diabetes mellitus is a clinical syndrome due to relative or absolute deficiency of insulin or resistance to the action of insulin at the cellular level as a result hyperglycemia and glycosuria occurs [1]. Various new therapies have been introduced such as inhibition of enzymes that are involved in hydrolysis of dietary polysaccharides in the gut which can lead to reduction in blood glucose levels after a meal by reducing the absorption of monosaccharide by the entrecotes of the small intestine. Enzymes that are involved in hydrolysis of dietary polysaccharides are pancreatic amylase and glycosidase. With the advancement in treatment strategy there is risk of side effect such as excessive inhibition of pancreatic amylase may lead to abdominal distention, flatulence and diarrhea. Currently available therapies for type II diabetes mellitus are as follows oral insulin secretagogues, sulfonylureas, repaglinide, nateglinide, biguanides, thiazolidinediones, alpha-glucosidase inhibitors, insulin, pramlintide and exenatide. Oral hypoglycemic drugs are valuable in the treatment of patients with type II diabetes mellitus (NIDDM). Sulphonylureas and biguanides are traditional drugs which are mainstay of treatment while there are certain new drugs available now [2,3]. Insulin is used as hypoglycemic agent in Type II diabetes mellitus [4]. The use of herbal medicines (medicinal plants or phytotherapy) has recently gained popularity in all over the world for their efficacy in Type II diabetes mellitus (Table 1 ) and some plants have minor side effects when given in large doses (Table 2). But there is lack of understanding the actual mechanism of action of these medicines. These medicines are used since centuries in Unani system of medicine and they have more efficacy and fewer or no side effects therefore emphasis should be given on herbal medicine because allopathic system of medicine has failed in providing health to all. Herbal medicines are only alternative medicine that can relieve the patients. Various research studies have been carried in all over the world to evaluate the efficacy of herbs in the treatment of Type II diabetes mellitus [5]. Medicinal plants have been used for the treatment of type II diabetes mellitus since ancient times, and for a long time type
II diabetes mellitus has been treated orally with herbal medicines or their extracts, because plant products are frequently prescribed due to their less toxicity than conventional medicines. Shanmugam et al. reported medicinal plants used for the treatment of type II diabetes mellitus [6]. Type II diabetes mellitus is associated with disturbances in learning, memory, and cognitive skills in the diabetic patients. A study was conducted to evaluate the effect of chronic intraperitoneal administration of Apium graveolens on learning and memory in diabetic rats using passive avoidance and Y-maze tests. As a conclusion, it was suggested that Apium graveolens enhances the consolidation and recall capability of stored information in diabetic animals [7]. Zingiber officinale has been used in type II diabetes mellitus [8-11]. Thomson et al. study shows that Allium sativum has anti-diabetic and hypolipidemic properties in streptozotocin-induced diabetic rats [12]. According to one study, it has been determined that the Withania somnifera root and leaf extracts possess antidiabetic activities in alloxan-induced diabetic rats. Withania somnifera root extract contained more flavonoids than leaf extract [13]. In one study, the hypoglycemic effect of the rhizomes of Smilax glabra (Liliaceae) was investigated in normal and diabetic mice. The methanol extract of Smilax glabra reduced the blood glucose of normal mice and also significantly lowered the blood glucose of diabetic mice. This study shows that Smilax glabra has hypoglycemic effect [14] The discovery and use of modern medicine led to a dramatic decline in the occurrence of diseases. The harmful toxic effects of synthetic drugs

*Corresponding author: Muhammad Akram, Department of Eastern Medicine and Surgery, Faculty of Medical and Health Sciences, The University of Poonch Azad Jammu and Kashmir, Pakistan, E-mail: makram_0451@yahoo.com, makram_0451@hotmail.com

Received September 20, 2013; Accepted October 25, 2013; Published October 30, 2013

Citation: Akram M (2013) Diabetes Mellitus Type II: Treatment Strategies and Options: A Review. J Diabetes Metab 4: 304. doi:10.4172/2155-6156.1000304

Copyright: (c) 2013 Akram M. This is an open-access article distributed under the terms of the Creative Commons Attribution License, which permits unrestricted use, distribution, and reproduction in any medium, provided the original author and source are credited. 
Citation: Akram M (2013) Diabetes Mellitus Type II: Treatment Strategies and Options: A Review. J Diabetes Metab 4: 304. doi:10.4172/21556156.1000304

Page 2 of 9

\begin{tabular}{|c|c|c|c|}
\hline 1 & Viscum album & Viscaceae & Gray and Flatt 1999 [71] \\
\hline 2 & Butea monosperma & Fabaceae & Sharma and Garg 2009 [72] \\
\hline 3 & Syzygium alternifolium & Myrtaceae & Rao and Rao 2001 [73] \\
\hline 4 & Catheranthus roseus & Apocynanceae & Karuna et al. 2010 [74] \\
\hline 5 & Capsicum frutescens $\mathrm{L}$. & Solanaceae & Islam and Choi $2008[10,11]$ \\
\hline 6 & Brassica juncea & Brassicaceae & Yadav et al. 2004 [75] \\
\hline 7 & Asparagus racemosus & Asparagaceae & Hannan et al. 2011 [76] \\
\hline 8 & Asparagus officinalis $\mathrm{L}$. & Asparagaceae & Zhao et al. 2011 [77] \\
\hline 9 & Piper betle & Piperaceae & Santhakumari et al. 2006 [78] \\
\hline 10 & Psidium guajava & Myrtaceae & Ojewole et al. 2008 [79] \\
\hline 11 & Mangifera indica & Anacardiaceae & Aderibigbe et al. 1999 [80] \\
\hline 12 & Sesamum indicum & Pedaliaceae & Takeuchi et al. 2001 [48] \\
\hline 13 & Ferula persica & Apiaceae & Hamdan and Afifi 2004 [81] \\
\hline 14 & Artemisia dracunculus & Asteraceae & Ribnicky et al. 2005 [82] \\
\hline 15 & Abutilon hirtum & Malvaceae & Krisanapun et al. 2009 [83] \\
\hline 16 & Abroma augusta & Sterculiaceae & Tariqul et al. 2012 [84] \\
\hline 17 & Helicteres isora L. & Sterculiaceae & Suthar et al. 2009 [85] \\
\hline 18 & Garuga pinnata Roxb & Burseraceae & Shirwaikar et al. 2006 [86] \\
\hline 19 & Breynia retusa & Euphorbiaceae & Kripa et al. 2011 [87] \\
\hline 20 & Albizia odoratissima & Fabaceae & Kumar et al. 2011 [88] \\
\hline 21 & Ageratum conyzoides L. & Asteraceae & Agunbiade et al. 2012 [89] \\
\hline 22 & Aerva lanata & Amaranthaceae & Vetrichelvan et al. 2002 [45] \\
\hline 23 & Syzygium cumini & Myrtaceae & Sharma et al. 2012 [90] \\
\hline 24 & Solanum surattense & Burm Solanaceae & Poongothai et al. 2011 [91] \\
\hline 25 & Ocimum canum $\mathrm{L}$ & Lamiaceae & Nyarko et al. 2002 [92] \\
\hline 26 & Enicostemma hyssopifolium & Gentianaceae & Patel and Mishra 2011 [93] \\
\hline 27 & Azadirachta indica & Meliaceae & Khosla et al. 2000 [94] \\
\hline 28 & Artemisia herba & Asteraceae & Al-Shamaony et al. 1994 [95] \\
\hline 29 & Costus speciosus & Costaceae & Bavarva et al. 2008 [96] \\
\hline 30 & Oenanthe javanica & Apiaceae & Yang et al. 2000 [97] \\
\hline 31 & Gymnema sylvestre & Asclepiadaceae & Al-Romaiyan et al. 2010, Baskaran et al. $1990[98,99]$ \\
\hline 32 & Catharanthus roseus & Apocynaceae & Rasineni et al. 2010 [74] \\
\hline 33 & Moringa oleifera & Moringaceae & Gupta et al. 2012 [100] \\
\hline
\end{tabular}

Table 1: List of plants having hypoglycemic activity.

\begin{tabular}{|c|c|c|}
\hline Plant Name & Side effects in human & Dose \\
\hline Anacardium occidentale linn & Dermatitis & 2-25 grams per day \\
\hline Tribulus terrestris & $\begin{array}{l}\text { Sleep disturbance and irregular periods. Tribulus terrestris can interact } \\
\text { with some heart medicine and increase their effect in the body such as } \\
\text { beta blockers and digoxin }\end{array}$ & 5-7 grams per day \\
\hline Ricinus communis L. & Excessive use in any form is harmful for stomach & Seeds $3-5$ in number, leaves $7-12$ gram, fixed oil $25-50 \mathrm{ml}$ \\
\hline Aloe vera & $\begin{array}{l}\text { Aloe should not be taken internally during pregnancy, since it can stimulate } \\
\text { contraction }\end{array}$ & $125-500 \mathrm{mg}$ \\
\hline Hyssopus officinalis & Its use is contraindicated in patients suffering from liver affections & 3-7 grams \\
\hline Trigonella foenum-graecum $\mathrm{L}$. & Long term use may produce headache and nausea & 3-5 grams \\
\hline Smilax chinensis & Excessive use may produce dryness & 5-7 grams \\
\hline Urginea indica & Nausea, convulsion and paralysis & 3-5 grams \\
\hline Acacia nilotica & Prolonged use causes constipation & Bark: 3-5 gram, gum: 1-3 grams, extract: 1 gram \\
\hline Achyranthes aspera & The plant seeds may cause emesis and decrease appetite & $\begin{array}{l}5-7 \text { grams (Plant) } \\
500 \text { mg (Salt) }\end{array}$ \\
\hline Aegle marmelos & Excessive use may cause obstruction and hemorrhoids & $\begin{array}{l}\text { Fresh fruit: } 24-48 \text { grams } \\
\text { Dry pulp (in powdered from) } 2-3 \text { grams }\end{array}$ \\
\hline Laurus nobilis & Stomatitis, cheilitis and dermatitis & 1-2 grams \\
\hline Curcuma longa & Curcuminoids may possibly cause stomach ulcer & $1-3$ grams \\
\hline Sesamum indicum & Flatulence & $7-12$ grams \\
\hline Allium cepa $\mathrm{L}$. & Headache and hyperuricemia & $\begin{array}{l}\text { Juice: } 24-36 \text { grams } \\
\text { Seeds: } 1-3 \text { grams }\end{array}$ \\
\hline Semecarpus anacardium linn & Blisters, swelling, painful micturation, inflammation, and pharyngitis & $\begin{array}{l}\text { Seeds kernels: } 250-500 \\
\text { Juice of pericarp: } 12-25\end{array}$ \\
\hline Matricaria chamomilla & Large doses may cause emesis & 1-3 grams \\
\hline Gymnema sylvestre & $\begin{array}{l}\text { When chewed, it temporarily paralyses the sense of taste for sweet and } \\
\text { bitter substances }\end{array}$ & 3-7 grams \\
\hline Ficus bengalensis & It may cause harmful effects on stomach and intestine & 3-5 grams \\
\hline
\end{tabular}

Table: 2 Side effects in human and dose [101]. 
led to alternative sources which would be safe and effective in various diseases. The present study is to document the medicinal plants used in type II diabetes mellitus.

\section{Materials and Methods}

The material for this review was taken mostly from endocrinology textbooks \& electronic journal Up to date. To collect publication Pub Med, Google scholars and the Cochrane database of systematic reviews was used. Some other relevant references were collected from personal database of papers on type II diabetes mellitus.

\section{Treatment of Type II Diabetes Mellitus}

\section{Oral hypoglycemic drugs}

Sulfonylureas: Sulfonylureas include tolbutamide, glibenclamide, chlorpropamide, glipizide, acetohexamide, gliclazide and tolazamide [15].

Biguanides: Phenformin and metformin [16].

Miscellaneous: Acarbose and guar gum.

\section{New drugs for NIDDM}

These include insulin sensitizers, drugs which reduce insulin resistance by interaction with the PPAR- (peroxisome proliferatorsactivated receptor-) a nuclear receptor which regulates genes involved in lipid metabolism. The effect on insulin sensitivity may result from decreased production of nonesterified fatty acids. They have the capacity to potentiate the effect of endogenous insulin. One of these, troglitazone, which belongs to the thiazolidinedione group, is used in Type II diabetes mellitus. Repaglinide, a benzoic acid derivation which stimulates insulin production at meal times has been used in type II diabetes mellitus patients [17].

DPP-4 inhibitors: Drugs targeting the incretin pathway are the latest addition to the available antidiabetic agents. Incretin-based therapy is either delivered orally (dipeptidyl peptidase-4 [DPP4]) inhibitors or injected subcutaneously (glucagon-like peptide-1 [GLP-1] mimetics and analogues). Dipeptidyl peptidase-4 inhibitors are effective either as a single or combination therapy in lowering glycated hemoglobin, fasting and postprandial glucose levels, with a low incidence of hypoglycemia and no weight gain. There are 3 DPP-4 inhibitors currently available (sitagliptin, saxagliptin, and vildagliptin), with more expected to be available in the future. DPP-4 inhibitors are effective in the treatment of patients with type 2 diabetes [18].

Incretin mimetics: Incretin-related therapies offer great potential for the treatment of people with type II diabetes mellitus. Major incretins that affect glucose metabolism are GLP-1: glucagon-like peptide-1 and GIP: glucose-dependent insulinotropic polypeptide. These therapies have a unique mechanism of action that addresses glucose appearance as well as glucose disappearance [19].

Thiazolidinediones: The thiazolidinediones also known as glitazones, are a class of medications that are used in the treatment of diabetes mellitus type 2. They were introduced in the late 1990s [20].

Alpha glucosidase inhibitors: One alternative approach o the treatment of overweight patients with NIDDM is to use drugs which inhibit the enzymes involved in the breakdown of carbohydrates in the intestine. Acarbose is a sham sugar that competitively inhibits a-glucosidase enzymes situated on the brush border of the intestine. As a result, dietary carbohydrates are poorly absorbed, and the postprandial rise in blood glucose is reduced. Undigested starch enters the large intestine where it is broken down by fermentation. Abdominal discomfort, flatulence and diarrhea can result, and dosage needs careful adjustment to avoid these side effects. Very little acarbose enters the circulation, since it is mainly inactivated in the gut, but liver dysfunction may rarely occur with high doses [21].

\section{Medicinal Plants Possessing Alpha -Glucosidase Inhibitory Activities}

Glycosidases are involved in metabolic disorders including type II diabetes mellitus. Inhibition of these glycosidase may be proved effective in type II diabetes mellitus. Various medicinal plants have been evaluated for their efficacy to inhibit glucosidase. Euonymus sachalinensis, Rhododendron schlippenbachii, Astilbe chinensis and Juglans regia have inhibitory effect on glucosidase, therefore can be a potential natural source for the treatment of type II diabetes mellitus [22].

\section{Tussilago farfara}

Family: Asteraceae. Chemical constituents: It contains mucilage, tannin, phytosterol, dihydride alcohol and faradial. Medicinal uses: It is used in catarrh, colds, whooping cough, respiratory problems, spasmodic lung problem, stomach trouble, inflammation and bleeding. Pharmacological activity: It is anti-inflammatory, anti-spasmodic and hypoglycemic. Study: Gao et al. reported the $\alpha$-glucosidase inhibitory activity of this plant and concluded that flower bud of Tussilago farfara is useful in type II diabetes mellitus [23].

\section{Medicinal Plants Used as Hypoglycemic Agents}

\section{Prinsepia utilis Royle}

Family: Rosaceae, Parts used: Aerial parts. Chemical constituents: It contains pentacyclic triterpenoids. Medicinal uses: Oil from seeds is rubifacient and is applied locally in rheumatism. Pharmacological activity: It is anti-inflammatory, anti-arthritic and hypoglycemic. Study: A study was conducted to investigate the anti-hyperglycemic activity of flavonoids from Prinsepia utilis Royle in alloxan-induced diabetic mice. Study duration was four weeks. Drug was administered orally. Dose of drug was $300 \mathrm{mg} / \mathrm{kg}$ of flavonoids from Prinsepia utilis Royle. There was significant hypoglycemic activity of Flavonoids from Prinsepia utilis Royle compared with model control group $(\mathrm{P}<0.01)$ [24].

\section{Ricinus communis $\mathrm{L}$.}

Family: Euphorbiaceae, Common name: Harnoli. Parts used: Root, leave, oil. Chemical constituents: It contains ricinolein, flavonoids, ricin, ricinolic acid, sodium ricinoleate, tristearin. Medicinal uses: It is used in constipation, pain and inflammation. Pharmacological activity: It is anti-inflammatory, laxative and hypoglycemic. Study: Hypoglycemic activity of 50\% ethanolic extract of roots of Ricinus communis was investigated. Effective dose was 500 $\mathrm{mg} / \mathrm{kg}$ body weight. There was significant decrease in fasting blood glucose level. Hypoglycemic activity was observed in normal as well as diabetic animal model. Study duration was 20 days. There was significant reduction in lipid profile and liver and kidney functions were normal during the study period. Fractionation of this extract was done and these were tested for antihyperglycemic activity. Fraction (R-18) exhibited significant hypoglycemic activity. This drug was safe because there was no effect on liver and kidney function and all enzymes were normal [25]. 


\section{Aloe vera}

Family: Xanthorrhoeaeceae, Chemical constituents: It contains anthraquinone glycosides, free anthaquinones, resins, glucomannan, steroids, organic acids, enzymes, antibiotic principles, amino acids, cinnamic acid and salicylic acid, essential oil. Medicinal uses: It is used in inflammation, wounds and bacterial infections. Pharmacological activity: It is soothing, anti-inflammatory, emmengogue, emollient, and antibacterial. Study: Rajasekaran et al. reported the hypoglycemic effect of Aloe vera gel on streptozotocin-induced hyperglycemia in experimental rats [26]. Okyar et al. reported the antidiabetic effect of Aloe vera in type II diabetic rat models [27].

\section{Crataeva nurvala Buch}

Family: Capparidaceae. Parts used: Leaves. Chemical constituents: It contains tannin and saponin. Medicinal uses: It is used in diabetes mellitus. Pharmacological activity: It is hypoglycemic. Study: Sikarwar and Patil reported the antidiabetic activity of Crateva nurvala stem bark extracts in alloxan-induced diabetic rats [28]

\section{Hyssopus officinalis}

Family: Lamiaceae. Chemical constituents: It contains glycosides, essential oil, tannins, resins, fats, sugar, mucilage, flavonoid glycoside. Medicinal uses: It is used in abdominal pain, respiratory tract infections, insomnia, constipation, viral infections and gastrointestinal disorders. Pharmacological activity: It is antispasmodic, expectorant, sedative, carminative, diaphoretic, antiviral, astringent, tonic and stomachic. Study: Miyazaki et al. has studied the inhibitory effect Hyssopus officinalis extracts on intestinal alpha-glucosidase activity and postprandial hyperglycemia [29].

\section{Trigonella foenum-graecum $\mathrm{L}$.}

Family: Fabaceae, English Name: Fenugreek. Local Name: Maithi. Chemical constituents: It contains trigonelline, flavonoid, glycosides, saponin, ascorbic acid, fenugreekine. Medicinal uses: It is used in type II diabetes mellitus, respiratory tract infections, swelling, body pain, stomach pain, piles, dandruff, baldness, breast pain, lungs infection, ulcer and diarrhea. Pharmacological activity: It is anti-inflammatory, tonic and hypoglycemic. Study: Trigonelline produces hypoglycemic effect in diabetic rats which lasts for 24 hours [30].

\section{Smilax chinensis}

Family: Liliaceae, Chemical constituents: It contains beta sitosterol, oil, diosgenin, smilacin, resin, tannin, starch, gum, sarsapogenin, sapogenins, parallin, sarsaponin and saponins. Medicinal uses: It is used in inflammation, cancer and type II diabetes mellitus. Pharmacological activity: It is anti-inflammatory and anti-diabetic. Study: The antidiabetic effects of the methanol extracts of the Smilax chinensis L. (MESC) on alloxan induced hyperglycemia were evaluated on albino wistar rats. Ethanolic extract of Smilax chinensis exhibited potential hypoglycemic effect with potential hypolipidemic effect (Venkidesh et al. 2010) [31]. The anti-diabetic effects of the methanol extracts of the Smilax chinensis L. on alloxan induced hyperglycemia were evaluated on albino wistar rats. Ethanolic extract of Smilax chinensis exhibited a potential hypoglycemic effect with potential hypolipidemic effect [32].

\section{Salvadora oleoides Decne}

Family: Salvadoraceae, Common name: Peelu. Parts used: Fruit, root, seed. Medicinal uses: It is used in anemia, constipation and pyorrhea. Pharmacological activity: It is anti-anemic, laxative and anti-septic. Study: Yadav et al. reported the hypoglycemic activity of ethanolic extract of Salvadora oleoides [33].

\section{Urginea indica}

Family: Liliaceae. Tibbi name: Jangli Piyaz. Chemical constituents: It contains glycosides, scillaren A and scillaren B. Medicinal uses: It is used in urinary tract infections and type II diabetes mellitus. Pharmacological activity: It is anti-septic and hypoglycemic. Study: The extract of this plant has hypoglycemic activity [34].

\section{Acacia nilotica}

Family: Fabaceae; Local name: Kikar; Parts used: Wood, leave and gum. Chemical constituents: It contains gum arabic, tannins, mucilage, magnesium, potassium, calcium, catechin, arabic acid, malic acid and flavonoid compounds. Medicinal uses: It is prescribed for treatment of type II diabetes mellitus. Pharmacological activity: It is astringent and hypoglycemic. Study: Usmanghani et al. documented its anti-diabetic activity [35].

\section{Achyranthes aspera}

Family: Amaranthaceae; Parts used: Leaves, stems and roots. Chemical constituents: Saponins, ecdysterone, inokosterone, achyranthine, and potassium, ash of leaves, stems and root contains considerable amount of potassium. Medicinal uses: It is used in diabetes mellitus. Pharmacological activity: It is hypoglycemic. Study: A study was conducted to evaluate its efficacy in diabetic rat. Alcoholic extract of whole plant was given to albino rat. Alcoholic extract exhibited hypoglycemic activity in albino rats [36].

\section{Luffa aegyptiaca Mill}

Family: Cucurbitaceae; Medicinal uses: It is used in joint pain, backache, colic, splenitis and phlegmatic diseases. Pharmacological activity: It is anti-inflammatory and hypoglycemic. Study: El-Fiky et al. investigated the efficacy of oral administration of the ethanolic extracts of Luffa aegyptiaca on blood glucose levels both in normal and streptozotocin diabetic rats. Hypoglycemic activity was observed significantly in streptozocin diabetic rats during the first three hours of treatment. In normal rats, hypoglycemic activity was insignificant compared to glibenclamide treatment [37].

\section{Citrus paradisi}

Family: Rutaceae; Medicinal uses: It is used in diabetes mellitus type II and bacterial infections. Pharmacological activity: Antibacterial and hypoglycemic. Study: Adeneye reported that methanol seed extract of Citrus paradisi lowers blood glucose, lipids and cardiovascular disease risk indices in normal Wistar rats [38]

\section{Aegle marmelos}

Family: Rutaceae; Part used: Fruits, leaves. Medicinal uses: It is used in chronic constipation, piles, dysentery, hyperacidity, abdominal pain and type II diabetes mellitus. Pharmacological activity: It is mucilaginous, antidiabetic and antidysentric. Study: A study was conducted on normal and diabetic rats. Fruit of this plant exhibited hypoglycemic activity in normal rats [39].

\section{Cymbopogan citratus}

Family: Poaceae; Medicinal uses: It is used in type II diabetes mellitus, gouty arthritis and tuberculosis. Pharmacological activity: It is anti-inflammatory and hypoglycemic. Study: Mirghani et al. documented the hypoglycemic activity [40]. 


\section{Momordica balsamina $\mathrm{L}$.}

Family: Cucurbitacea. Common name: Jangli Kareela. Parts used: Fruit and seeds. Chemical constituents: It contains vitamin $\mathrm{C}$ and momorcidin. Medicinal uses: It is used in type II diabetes mellitus, gas trouble, constipation, flatulence, obesity, boils and pimples. Pharmacological activity: It is hypoglycemic, stomachic and blood purifier. Study: Leung et al. stated its anti-diabetic and hypoglycemic activity [41].

\section{Psidium guajava L.}

Family: Myrtaceae. Common name: Amrood. Parts used: Leaves, fruit. Medicinal uses: It is used in type II diabetes mellitus and intestinal worms. Pharmacological activity: It is tonic and anti-diabetic. Study: Shen et al. reported the hypoglycemic activity of Psidium guajava Linn. in type II diabetic patients [42].

\section{Syzygium cumini}

Family: Myrtaceae. Common name: Jaman, Parts used: Leave, bark, fruit, nut. Chemical constituents: It contains myrcetin, kaemferol, isoquercetin, ellagic acid, glucosides, anthocyanins, alakloids, jambolin, jambosine and antimellin. Medicinal uses: It is used in fever, motion, vomiting, anemia, painful swellings and type II diabetes mellitus. Pharmacological activity: It is anti-inflammatory and hypoglycemic. Study: It prevents oxidative damage in diabetic rats [43].

\section{Morus alba $\mathrm{L}$.}

Family: Moraceae. Common name: Shehtoot, Parts used: Leave, fruit. Chemical constituents: It contains polyphenol pigment, anthocyanins, resveratrol, vitamin $\mathrm{C}$, carotene, zea xanthin, iron, magnesium, manganese and potassium. Medicinal uses: It is used in sore throat, cough and abdominal worms. Pharmacological activity: It is anthelmintic and hypoglycemic. Study: Mohammadi and Naik reported the hypoglycemic activity and are prescribed to treat diabetes mellitus type II [44].

\section{Aerva lanata}

Chemical constituents: It contains galactoside and kampferol. Medicinal uses: It is used in kidney stones, constipation and diabetes mellitus type II. Pharmacological activity: Diuretic, purgative, emetic and hypoglycemic. Study: Vetrichelvan and Jegadeesan reported the anti-diabetic activity of alcoholic extract of Aerva lanata in rats and concluded that this plant can be prescribed to treat diabetes mellitus type II [45].

\section{Laurus nobilis}

Parts used: Leaf and berry, Chemical constituents: It contains cineole, eugenol, geraniol, alpha and beta pinene, lauric acid, palmitic acid, linoleic acid, reticuline, boldine, laurostearine, methyl eugenol. Medicinal uses: It is used in hysteria, colic, indigestion, loss of appetite. Pharmacological activity: It is antirheumatic, antiseptic, bactericidal, digestive, diuretic, emmenagogue, stomachic, hypotensive and sedative. Study: Khan et al. reported that Bay leaves improve glucose and lipid profile of people with type II diabetes mellitus [46].

\section{Curcuma longa}

Family: Zingiberaceae. Parts used: Tubers and rhizomes. Chemical constituents: It contains essential oil, turmerol, curcumin, sesquiterpenic ketone, arturmerone, bisabolane, curlone, guaiane, tumerone, zingiberone. Medicinal uses: It is used in whooping cough, asthma, bronchitis, scabies, irritation, chronic skin disorders, wounds, strokes, bruises, eczema, prurigo and ringworm. Pharmacological activity: It is expectorant, blood purifier and hypoglycemic. Study: Suryanarayana et al. reported that curcumin and turmeric delay streptozotocin-induced diabetic cataract in rats [47].

\section{Sesamum indicum}

Family: Pedaliaceae. Tibbi name: Til, Kunjad. Chemical constituents: It contains molybdenum, thiamine, niacin, carbohydrates, methionine, tryptophan, lecithin, sesamin, sesamolin, phytosterol, cobalt, iodine, iron, zinc, calcium and sitosterol. Medicinal uses: It is used in cough, sexual debility, asthma, thorax complaints, inflammations and bleeding piles. Pharmacological activity: It is aphrodisiac, anti-inflammatory and hypoglycemic. Study: Takeuchi et al. documented hypoglycemic activity of this plant [48].

\section{Ginkgo biloba}

Family: Ginkgoaceae. Chemical constituents: It contains flavonoids and terpenoids. Medicinal uses: It is used in dementia, intermittent claudication, anxiety, glaucoma, macular degewneration, premenstrual syndrome, cardiovascular disorders and diabetes mellitus type II. Pharmacological activity: It is hypoglycemic and antioxidant. Study: Chen et al. reported that Ginkgo biloba extract reduces high-glucose-induced endothelial adhesion by inhibiting the redoxdependent interleukin-6 pathways [49].

\section{Ziziphus mauritiana Lam.}

Common names: Beri, Parts used: Leaves, fruit. Medicinal uses: It is used in type II diabetes mellitus. Pharmacological activity: It is hypoglycemic. Study: Bhatia and Mishra reported the hypoglycemic activity of Ziziphus mauritiana aqueous ethanol seed extract in alloxaninduced diabetic mice [50].

\section{Allium cepa L.}

Local name: Kashuh, Parts used: Leaves and bulbs. Chemical constituents: It contains phytoncides, vitamins, allicin, flavonoids, allylpropyl disulfide, essential oil, quercetin, scordine and fatty oil. Medicinal uses: It is used in ear pains, flatulence and skin diseases. Pharmacological activity: It is aphrodisiac and hypoglycemic. Study: Mathew and Augusti reported the hypoglycemic activity of Allium cepa and concluded that this plant can be prescribed to treat type II diabetes mellitus [51].

\section{Ammi visnaga}

Medicinal uses: It is used in angina and type II diabetes mellitus. Pharmacological activity: It is vasodilator and hypoglycemic. Study: Jouad et al. reported the hypoglycemic effect of aqueous extract of Ammi visnaga in normal and streptozotocin-induced diabetic rats [52].

\section{Berberis lyceum Royle}

Part used: Root, Medicinal uses: It is used in arthritis, osteoarthritis, inflammations, opthalmia, mouth ulcers, skin ulcers and conjunctivitis. Pharmacological activity: It is hypoglycemic and anti-inflammatory. Study: Gulfraz et al. reported the antidiabetic activity of Berberis lyceum root extract and berberine in alloxan-induced diabetic rats [53]

\section{Hippophea rhamnoide L.}

Parts used: Fruit, stem, and leaves. Medicinal uses: It is used in skin problems, lung problems, cancer, ulcer, wounds, skin infection, joint pain, hair fall, type II diabetes mellitus, and blood pressure, 
jaundice and heart problems. Pharmacological activity: It is antidiabetic. Study: Arshad and Bibi reported the ethnomedicinal uses of Hippophea rhamnoide L. in type II diabetes mellitus [54]

\section{Lavandula stoechas}

Arabic name: Mumsik al-Arwah, Persian name: Anis alArwah, Ustukhudoos. English name: Arabian Lavender. Chemical constituents: It contains fenchone, sitosterol, ursolic acid, lavanol, camphor, and 7-methoxy coumarin. Medicinal uses: It is used in neuralgic headache, thoracic diseases and type II diabetes mellitus. Pharmacological activity: It is deobstuent, resolvent and tonic. Study: Gámez et al. reported the hypoglycemic activity in various species of the genus Lavandula and concluded that it can be used as hypoglycemic agent in patients with type II diabetes mellitus [55].

\section{Panax ginseng}

Family: Araliacaea. Medicinal uses: It is used in asthma, bronchitis, altitude sickness and type II diabetes mellitus. Pharmacological activity: It is anti-diabetic. Study: Attele et al. reported the anti-diabetic effects of Panax ginseng berry extract [56].

\section{Fagopyrum tataricum}

Family: Polygonaceae. Parts used: Leaves. Medicinal uses: It is used in diabetes mellitus. Pharmacological activity: It is hypoglycemic. Study: Lee et al. reported that Fagopyrum tataricum (buckwheat) improves high-glucose-induced insulin resistance in mouse hepatocytes and type II diabetes mellitus in fructose-rich diet-induced mice [57].

\section{Semecarpus anacardium linn}

Family: Anacardiaceae. Parts used: Fruit, seeds, gum, oil, juice of pericarb, seed kernels. Chemical constituents: It contains tryptophan, phenylalanine, nicotinic acid, riboflavin, thiamine, bhilanwanol, fixed oil, anacardol, catechol, cardol, anacardic acid. Medicinal uses: It is used in infected wounds, boils and type II diabetes mellitus. Pharmacological activity: It is antiseptic and hypoglycemic. Study: Khan et al. reported the antidiabetic and antioxidant effect of Semecarpus anacardium Linn. nut milk extract in a high-fat diet STZinduced type 2 diabetic rat model [58].

\section{Glycyrrhiza glabra}

Family: Fabacaea. Parts used: Roots. Medicinal uses: It is used in obesity, peptic ulcers, stress, eczema, asthma, hay fever, arthritis, gastritis, abdominal colic, hyperacidity, heart burn, indigestion, constipation, cough, bronchitis and other respiratory infections. Pharmacological activity: It is expectorant, febrifuge, antibacterial, anti-inflammatory, anti-allergy, estrogenic, demulcent, antispasmodic, laxative, anti-allergic, antacid and antiseptic. Study: Aoki et al. reported the hypoglycemic activity of this plant [59].

\section{Matricaria chamomilla}

Medicinal uses: It is used in headache, chest pain and conjunctivitis. Pharmacological activity: It is stimulant, demulcent, brain tonic and diuretic. Study: Cemek et al. reported the antihyperglycemic and antioxidative potential of Matricaria chamomilla L. in streptozotocininduced diabetic rats and concluded that it can be prescribed to treat hyperglycemia [60].

\section{Gymnema sylvestre}

Medicinal uses: It is used in cardiovascular disorders and diabetes mellitus type II. Pharmacological activity: It is anti-oxidant and hypoglycemic agent. Study: Leach reported the antidiabetic activity of Gymnema sylvestre [61].

\section{Eugenia caryophyllus}

Parts used: Stems, leaves and dried flowers buds. Chemical constituents: It contains eugenol, beta caryophyllene and terpenic oxides. Medicinal uses: It is used in skin infections, digestive problems and toothache. Pharmacological activity: It is carminative, antiemetic, counterirritant, expectorant, anthelmintic, antirheumatic, antineuralgic, antiseptic, antiviral and anti-oxidant [62]. Study: Collip reported the hypoglycemic activity of alcoholic extract of Eugenia caryophyllus [63].

\section{Ajugaiva L}

Family: Lamiaceae. Medicinal uses: It is used in diabetes mellitus type II. Pharmacological activity: It is hypoglycemic. Study: A study was conducted to investigate the hypoglycemic activity of Ajuga iva L. in rat model. This plant is commonly available in Asia and Africa. Water extract of Ajuga iva L (AT) was administered to rats at a dose of $10 \mathrm{mg}$ / $\mathrm{kg}$ that reduced blood glucose level in rats 6 hours. This study indicates that Ajuga iva L. has hypoglycemic activity and validates its traditional use in hyperglycemic conditions [64].

\section{Tribulus terrestris}

Family: Zygophyllaceae. Medicinal uses: It is used in urinary tract infection and type II diabetes mellitus [65]. Pharmacological activity: It is diuretic, lithotriptic, anti-inflammatory and hypoglycemic. Study: A study was conducted to evaluate the efficacy of Tribulus terrestris in alloxan induced diabetic rats. After treatment, it was concluded that Tribulus terrestris has prominent antidiabetic effect [66].

\section{Anacardium occidentale linn}

Family: Anacardiacea, Part used: Leaves and fruit. Medicinal uses: It is used in diabetes mellitus type II. Pharmacological activity: It is anti-diabetic. Study: Ojewole reported the hypoglycemic effect of Anacardium occidentale Linn (Anacardiaceae) stem-bark extracts in rats [67].

\section{Bougainvillea glabra}

Family: Nyctaginaceae, Parts used: Leaves, flowers and stems. Chemical constituents: It contains alkaloids, flavonoids, pinitol and betacynin. Medicinal uses: It is used in inflammation and diabetes mellitus type II. Pharmacological activity: It is anti-inflammatory, insecticidal and hypoglycemic. Study: Bhat et al. reported the antidiabetic properties of Bougainvillea spectabilis. This study justifies its use as herbal drug in type II diabetes mellitus [68].

\section{Ferula assafoetida}

Family: Umbelliferae. Chemical constituents: It contains organic sulphur compounds, volatile oil, foetidae, luteolin. The gum resins contain coumarins, 5-hydroxyumbelliprenin, assafoetidin, ferocolicin, asacoumarin A and B, farnesiferol A, B, C and disulphide, asadisulphide and sec-butylpropenyl disulphide. Medicinal uses: It is used in constipation, abdominal pain, cough, intestinal worms, urinary tract infections and sexual disorders. Pharmacological activity: It is stimulant, carminative, antispasmodic, expectorant, slightly laxative, anthelmintic, diuretic, aphrodisiac, emmenagogue, nerve and pulmonary surfactant. Study: Abu-Zaiton reported the anti-diabetic activity of Ferula assafoetida extract in normal and alloxan-induced diabetic rats [69]. 


\section{Ficus bengalensis}

Family: Urticaceae. Parts used: Latex, bark, fruits, roots, root bark, buds and aerial roots. Chemical constituents: It contains triterpine, friedelin, sitosterol, tigilic acid, quercetin, rutin, tannins, waxes, albuminoids and carbohydrates. Medicinal uses: It is used in diabetes mellitus type II. Pharmacological activity: It is hypoglycemic. Study: Singh et al. reported the antidiabetic effect of Ficus bengalensis aerial roots in experimental animals [70].

\section{Conclusion}

Many herbs and plants have been described as possessing hypoglycemic activity when taken orally. Some of these plants have also been pharmacologically tested and shown to be of some value in human type II diabetes mellitus treatment. The efficacy of herbal drugs is significant and they have fewer side effects than the synthetic allopathic medicines. Further, phytochemical characterization of medicinal plants is required to identify the specific compound(s) involved in the observed hypoglycemic.

\section{Disclosure Statement}

None of the authors have a financial or proprietary interest in the subject matter or materials discussed in the manuscript, including, but not limited to, employment, consultancies, stock ownership, honoraria, and paid expert testimony.

\section{References}

1. Satyanarayana U, Chakrapani $A(2006)$ Insulin, glucose, homeostasis and diabetes mellitus. Biochem. Book and allied publisher India (3rdedn): 680-681.

2. Leopald EJ (1930) Aretaeus, the cappadocian. Ann Med Hist 2: 424-455.

3. Pickup W (1997) Textbook of Diabetes (2ndedn) London: Blackwell Science : $3-10$.

4. Hu G, Rico-Sanz J, Lakka TA, Tuomilehto J (2006) Exercise, genetics and prevention of type 2 diabetes. Essays Biochem 42: 177-192.

5. Lans CA (2006) Ethnomedicines used in Trinidad and Tobago for urinary problems and diabetes mellitus. J Ethnobiol Ethnomed 2: 45.

6. Shanmugam S, Manikandan K, Rajendran K (2009) Ethnomedicinal Survey of Medicinal Plants Used for the Treatment of Diabetes and Jaundice among the Villagers of Sivagangai District, Tamilnadu. Ethno Bot Leaflets 13: 189-194.

7. Mehrdad R, Amin A, Reza A (2009) The Effect of Chronic Administration of Apium Graveolens Aqueous Extract on Learning and Memory in Normal and Diabetic Rats. BCN 1: 26-28.

8. Saghir AJ, Sohail A, Muhammad Q (2011) Hypoglycemic Effect of Ginge (Zingiber officinale) in Alloxan Induced Diabetic Rats. Pak Vet J 31: 160-162.

9. Abeysekara W, Chandrasekara A, Liyanage P (2007) Amylase and glucosidase enzyme inhibitory activity of Zingiber officinale Roscoe an in vitro study. Trop Agri Res 19: 128-135.

10. Islam MS, Choi H (2008) Dietary red chilli (Capsicum frutescens L.) is insulinotropic rather than hypoglycemic in type 2 diabetes model of rats. Phytother Res 22: 1025-1029.

11. Islam MS, Choi $H$ (2008) Comparative effects of dietary ginger (Zingiber officinale) and garlic (Allium sativum) investigated in a type 2 diabetes model of rats. J Med Food 11: 152-159.

12. Thomson M, Al-Amin ZM, Al-Qattan KK (2007) Anti-diabetic and hypolipidaemic properties of Allium sativum in streptozotocin-induced diabetic rats. Int J Diab Metabolism 15: 108-115.

13. Udayakumar R, Kasthurirengan S, Mariashibu TS, Rajesh M, Anbazhagan VR, et al. (2009) Hypoglycaemic and hypolipidaemic effects of Withania somnifera root and leaf extracts on alloxan-induced diabetic rats. Int J Mol Sci 10: 2367 2382.

14. Fukunaga T, Miura T, Furuta K, Kato A (1997) Hypoglycemic effect of the rhizomes of Smilax glabra in normal and diabetic mice. Biol Pharm Bull 20: 44-46.
15. Wiwanitkit S, Wiwanitkit $\mathrm{V}$ (2011) Therapeutic goal of diabetes mellitus. Midlife Health 2: 94-95.

16. Dichtwald S, Weinbroum AA, Sorkine P, Ekstein MP, Dahan E (2012) Metformin-associated lactic acidosis following acute kidney injury. Efficacious treatment with continuous renal replacement therapy. Diabet Med 29: 245-250.

17. Tornio A, Niemi M, Neuvonen M, Laitila J, Kalliokoski A, et al. (2008) The Effect of gemfibrozil on repaglinide pharmacokinetics persists for at least $12 \mathrm{~h}$ after the dose: evidence for mechanism-based inhibition of CYP2C8 in vivo. Clin Pharmacol Ther 84: 403-411.

18. Palalau Al, Tahrani AA, Piya MK, Barnett AH (2009) DPP-4 inhibitors in clinical practice. Postgrad Med 121: 70-100.

19. Mikhail N (2008) Incretin mimetics and dipeptidyl peptidase 4 inhibitors in clinical trials for the treatment of type 2 diabetes. Expert Opin Investig Drugs 17 845-853.

20. Krentz AJ, Friedmann PS (2006) Type 2 diabetes, psoriasis and thiazolidinediones. Int J Clin Pract 60: 362-363.

21. Chiasson JL, Josse RG, Gomis R, Hanefeld M, Karasik A, et al. (2003) Acarbose treatment and the risk of cardiovascular disease and hypertension in patients with impaired glucose tolerance: the STOP-NIDDM trial. JAMA 290: 486-494.

22. Shruti S, Sandesh S (2011) Screening of Korean Medicinal Plant Extracts for Alpha -Glucosidase Inhibitory Activities. Int J Pharm Res 10: 261-264.

23. Gao H, Huang Y, Gao B, Xu P, Inagaki C, et al. (2008) a-Glucosidase inhibitory effect by the flower buds of Tussilago farfara L. Food Chemistry 106: 11951201.

24. Jia RY, Yin ZQ, Wu XL, Liu DB, Du YH, et al. (2008) [Hypoglyceminc effect of flavonoids from Prinsepia utilis on alloxan-induced diabetic mice]. Zhong Yao Cai 31: 399-403.

25. Shokeen P, Anand P, Murali YK, Tandon V (2008) Antidiabetic activity of $50 \%$ ethanolic extract of Ricinus communis and its purified fractions. Food Chem Toxicol 46: 3458-3466.

26. Rajasekaran S, Sivagnanam K, Ravi K, Subramanian S (2004) Hypoglycemic effect of Aloe vera gel on streptozotocin-induced diabetes in experimental rats. J Med Food 7: 61-66.

27. Okyar A, Can A, Akev N, Baktir G, Sütlüpinar N (2001) Effect of Aloe vera leaves on blood glucose level in type I and type II diabetic rat models. Phytother Res 15: 157-161.

28. Sikarwar MS, Patil MB (2010) Antidiabetic activity of Crateva nurvala stem bark extracts in alloxan-induced diabetic rats. J Pharm Bioallied Sci 2: 18-21.

29. Miyazaki H, Matsuura H, Yanagiya C, Mizutani J, Tsuji M, et al. (2003) Inhibitory effects of hyssop (Hyssopus officinalis) extracts on intestinal alpha-glucosidase activity and postprandial hyperglycemia. J Nutr Sci Vitaminol (Tokyo) 49: $346-$ 349 .

30. Pandiya C, Vohora B (1989) Research and development of indigenous drugs, Institute of history of medicine and medical research. Hamdard Nagar, New Delhi, India: 45-49.

31. Venkidesh R, Mandal SC, Pal D, Lakshmi SM, Saravanakumar A (2010) Antidiabetic activity of Smilax chinensis in alloxan induced diabetic rats. Phytomed 2: $51-54$.

32. Rajesh Bhati, Anupama Singh, Vikas Anand Saharan, Veerma Ram, Anil Bhandari (2011) Pharmacognostical standardization, extraction and anti-diabetic activity of Smilax china L. rhizome. A J Trad Med 6: 218-223.

33. Yadav JP, Saini S, Kalia AN, Dangi AS (2008) Hypoglycemic and hypolipidemic activity of ethanolic extract of Salvadora oleoides in normal and alloxaninduced diabetic rats. Indian J Pharmacol 40: 23-27.

34. The Wealth of India (1976) A dictionary of Indian Raw Material and Industria products, Volume $\mathrm{X}, \mathrm{Sp}-\mathrm{W}$, Council of Scientific and Industrial research, New Delhi, India: 87-83.

35. Usmanghani K, Saeed A, Alam T (1997) Indusyunic Medicine, Department of Pharmacognosy, faculty of pharmacy, University of Karachi: 90-92.

36. Atta R, Viqar U (1986) Pak Encyclopaedia Planta Medica, Hamdard foundation Pakistan 1: 56-60.

37. El-Fiky FK, Abou-Karam MA, Afify EA (1996) Effect of Luffa aegyptiaca (seeds) and Carissa edulis (leaves) extracts on blood glucose level of normal and streptozotocin diabetic rats. J Ethnopharmacol 50: 43-47. 
38. Adeneye AA (2008) Methanol seed extract of Citrus paradisi Macfad lowers blood glucose, lipids and cardiovascular disease risk indices in normal Wistar rats. Nig Q J Hosp Med 18: 16-20.

39. Rastogi P, Mehrotra N (1993) Compendium of Indian medicinal plants, volume II, (1970-1979) Centrai drug research institute, Lucknow, Publications and information directorate, New Delhi, India: 56-60.

40. Mirghani M, Liyana Y, Parveen J (2012) Bioactivity analysis of lemongrass (Cymbopogan citratus) essential oil. International Food Res J 19: 569-575.

41. Leung L, Birtwhistle R, Kotecha J, Hannah S, Cuthbertson S (2009) Anti-diabetic and hypoglycaemic effects of Momordica charantia (bitter melon): a mini review. Br J Nutr 102: 1703-1708

42. Shen SC, Cheng FC, Wu NJ (2008) Effect of guava (Psidium guajava Linn.) leaf soluble solids on glucose metabolism in type 2 diabetic rats. Phytother Res 22: $1458-1464$

43. De Bona KS, Bellé LP, Sari MH, Thomé G, Schetinger MR, et al. (2010) Syzygium cumini extract decrease adenosine deaminase, 5 'nucleotidase activities and oxidative damage in platelets of diabetic patients. Cell Physiol Biochem 26: 729-738.

44. Mohammadi J, Naik PR (2008) Evaluation of hypoglycemic effect of Morus alba in an animal model. Indian J Pharmacol 40: 15-18.

45. Vetrichelvan T, Jegadeesan M (2002) Anti-diabetic activity of alcoholic extrac of Aerva lanata (L.) Juss. ex Schultes in rats. J Ethnopharmacol 80: 103-107.

46. Khan A, Zaman G, Anderson RA (2009) Bay leaves improve glucose and lipid profile of people with type 2 diabetes. J Clin Biochem Nutr 44: 52-56.

47. Suryanarayana P, Saraswat M, Mrudula T, Krishna TP, Krishnaswamy K, et al (2005) Curcumin and turmeric delay streptozotocin-induced diabetic cataract in rats. Invest Ophthalmol Vis Sci 46: 2092-2099.

48. Takeuchi H, Mooi LY, Inagaki Y, He P (2001) Hypoglycemic effect of a hotwater extract from defatted sesame (Sesamum indicum L.) seed on the blood glucose level in genetically diabetic KK-Ay mice. Biosci Biotechnol Biochem 65: 2318-2321.

49. Chen JS, Chen YH, Huang PH, Tsai HY, Chen YL, et al. (2012) Ginkgo biloba extract reduces high-glucose-induced endothelial adhesion by inhibiting the redox-dependent interleukin-6 pathways. Cardiovasc Diabetol 11: 49.

50. Bhatia A, Mishra T (2010) Hypoglycemic activity of Ziziphus mauritiana aqueous ethanol seed extract in alloxan-induced diabetic mice. Pharm Biol 48: 604610.

51. Mathew PT, Augusti KT (1975) Hypoglycaemic effects of onion, Allium cepa Linn. on diabetes mellitus - a preliminary report. Indian J Physiol Pharmacol 19: 213-217.

52. Jouad H, Maghrani M, Eddouks M (2002) Hypoglycemic effect of aqueous extract of Ammi visnaga in normal and streptozotocin-induced diabetic rats. $J$ Herb Pharmacother 2: 19-29.

53. Gulfraz M, Mehmood S, Ahmad A, Fatima N, Praveen Z, et al. (2008) Comparison of the antidiabetic activity of Berberis lyceum root extract and berberine in alloxan-induced diabetic rats. Phytother Res 22: 1208-1212.

54. Arshad A, Bibi G (2012) Ethnomedicinal uses of plant resources in Gilgit-Baltistan of Pakistan. J Med Plants Res 6: 4540-4549.

55. Gámez MJ, Jiménez J, Risco S, Zarzuelo A (1987) Hypoglycemic activity in various species of the genus Lavandula. Part 1: Lavandula stoechas L. and Lavandula multifida L. Pharmazie 42: 706-707.

56. Attele AS, Zhou YP, Xie JT, Wu JA, Zhang L, et al. (2002) Antidiabetic effects of Panax ginseng berry extract and the identification of an effective component. Diabetes 51: 1851-1858.

57. Lee CC, Hsu WH, Shen SR, Cheng YH, Wu SC (2012) Fagopyrum tataricum (buckwheat) improved high-glucose-induced insulin resistance in mouse hepatocytes and diabetes in fructose-rich diet-induced mice. Exp Diabetes Res 2012: 375673

58. Khan HB, Vinayagam KS, Sekar A, Palanivelu S, Panchanadham S (2012) Antidiabetic and antioxidant effect of Semecarpus anacardium Linn nut milk extract in a high-fat diet STZ-induced type 2 diabetic rat model. J Diet 19-33.

59. Aoki F, Nakagawa K, Kitano M, Ikematsu H, Nakamura K, et al. (2007) Clinical safety of licorice flavonoid oil (LFO) and pharmacokinetics of glabridin in healthy humans. J Am Coll Nutr 26: 209-218.
60. Cemek M, Kaga S, Simsek N, Buyukokuroglu ME, Konuk M (2008) Antihyperglycemic and antioxidative potential of Matricaria chamomilla $L$. in streptozotocin-induced diabetic rats. J Nat Med 62: 284-293.

61. Leach MJ (2007) Gymnema sylvestre for diabetes mellitus: a systematic review. J Altern Complement Med 13: 977-983.

62. Merchán Arenas DR, Acevedo AM, Vargas Méndez LY, Kouznetsov VV (2011) Scavenger Activity Evaluation of the Clove Bud Essential Oil (Eugenia caryophyllus) and Eugenol Derivatives Employing ABTS Decolorization. Sci Pharm 79: 779-791.

63. Collip JB (1940) An Anti-diabetogenic effect of a primary alcoholic extract of pituitary tissue administered orally. Can Med Assoc J 42: 109-113.

64. El Hilaly J, Lyoussi B (2002) Hypoglycaemic effect of the lyophilised aqueous extract of Ajuga iva in normal and streptozotocin diabetic rats. J Ethnopharmacol 80: 109-113.

65. Nahar N (1993) Traditional medicine (18thedn) Oxford and OBH Publishing Co. Pvt. Ltd., New Delhi: 205-209.

66. Raghavendra HG, Sen S, Rami Reddy YS, Sridhar C, Chakraborty R, et al. (2011) Synergistic activity of Tribulus terrestris and Annona Squamosa extracts against alloxan induced diabetes and hyperlipidemia in rats. IJPS 2: 12-23.

67. Ojewole JA (2003) Laboratory evaluation of the hypoglycemic effect of Anacardium occidentale Linn (Anacardiaceae) stem-bark extracts in rats. Methods Find Exp Clin Pharmacol 25: 199-204

68. Bhat M, Kothiwale SK, Tirmale AR, Bhargava SY, Joshi BN (2011) Antidiabetic Properties of Azardiracta indica and Bougainvillea spectabilis: In Vivo Studies in Murine Diabetes Model. Evid Based Complement Alternat Med 2011 : 561625

69. Abu-Zaiton AS (2010) Anti-diabetic activity of Ferula assafoetida extract in normal and alloxan-induced diabetic rats. Pak J Biol Sci 13: 97-100.

70. Singh RK, Mehta S, Jaiswal D, Rai PK, Watal G (2009) Antidiabetic effect of Ficus bengalensis aerial roots in experimental animals. J Ethnopharmacol 123 110-114.

71. Gray AM, Flatt PR (1999) Insulin-secreting activity of the traditional antidiabetic plant Viscum album (mistletoe). J Endocrinol 160: 409-414

72. Sharma N, Garg V (2009) Antidiabetic and antioxidant potential of ethanolic extract of Butea monosperma leaves in alloxan-induced diabetic mice. Indian $J$ Biochem Biophys 46: 99-105.

73. Rao BK, Rao CH (2001) Hypoglycemic and antihyperglycemic activity of Syzygium alternifolium (Wt.) Walp. seed extracts in normal and diabetic rats. Phytomedicine 8: 88-93.

74. Rasineni K, Bellamkonda R, Singareddy SR, Desireddy S (2010) Antihypergly cemic activity of Catharanthus roseus leaf powder in streptozotocin-induced diabetic rats. Pharmacognosy Res 2: 195-201.

75. Yadav SP, Vats V, Ammini AC, Grover JK (2004) Brassica juncea (Rai) significantly prevented the development of insulin resistance in rats fed fructoseenriched diet. J Ethnopharmacol 93: 113-116.

76. Hannan JM, Ali L, Khaleque J, Akhter M, Flatt PR, et al. (2011) Antihyperglycaemic activity of Asparagus racemosus roots is partly mediated by inhibition of carbohydrate digestion and absorption, and enhancement of cellular insulin action. Br J Nutr 8: 1-8

77. Zhao J, Zhang W, Zhu X, Zhao D, Wang K, et al. (2011) The aqueous extract of Asparagus officinalis $\mathrm{L}$. by-product exerts hypoglycaemic activity in streptozotocin-induced diabetic rats. J Sci Food Agric 91: 2095-2099.

78. Santhakumari P, Prakasam A, Pugalendi KV (2006) Antihyperglycemic activity of Piper betle leaf on streptozotocin-induced diabetic rats. J Med Food 9 108-112.

79. Ojewole JA, Awe EO, Chiwororo WD (2008) Antidiarrhoeal activity of Psidium guajava Linn. (Myrtaceae) leaf aqueous extract in rodents. J Smooth Muscle Res 44: 195-207.

80. Aderibigbe AO, Emudianughe TS, Lawal BA (1999) Antihyperglycaemic effect of Mangifera indica in rat. Phytother Res 13: 504-507.

81. Hamdan II, Afifi FU (2004) Studies on the in vitro and in vivo hypoglycemic activities of some medicinal plants used in treatment of diabetes in Jordanian traditional medicine. J Ethnopharmacol 93: 117-121. 
Citation: Akram M (2013) Diabetes Mellitus Type II: Treatment Strategies and Options: A Review. J Diabetes Metab 4: 304. doi:10.4172/21556156.1000304

Page 9 of 9

82. Ribnicky DM, Poulev A, Watford M, Cefalu WT, Raskin I (2006) Antihyperglycemic activity of Tarralin, an ethanolic extract of Artemisia dracunculus L. Phytomedicine 13: 550-557.

83. Krisanapun C, Peungvicha P, Temsiririrkkul R, Wongkrajang Y (2009) Aqueous extract of Abutilon indicum Sweet inhibits glucose absorption and stimulates insulin secretion in rodents. Nutr Res 29: 579-587.

84. Islam T, Rahman A, Islam AU (2012) Effects of Aqueous Extract of Fresh Leaves of Abroma augusta L. on Oral Absorption of Glucose and Metformin Hydrochloride in Experimental Rats. ISRN Pharm 2012: 472586.

85. Suthar M, Rathore GS, Pareek A (2009) Antioxidant and Antidiabetic Activity of Helicteres isora (L.) Fruits. Indian J Pharm Sci 71: 695-699.

86. Shirwaikar A, Rajendran K, Barik R (2006) Effect of aqueous bark extract of Garuga pinnata Roxb. in streptozotocin-nicotinamide induced type-II diabetes mellitus. J Ethnopharmacol 107: 285-290.

87. Kripa KG, Sangeetha R, Madhavi P, Deepthi P (2011) Phytochemical screening and in vitro amylase inhibitory effect of the leaves of Breynia retusa. Pak J Biol Sci 14: 894-899.

88. Kumar D, Kumar S, Kohli S, Arya R, Gupta J (2011) Antidiabetic activity of methanolic bark extract of Albizia odoratissima Benth. in alloxan induced diabetic albino mice. Asian Pac J Trop Med 4: 900-903.

89. Agunbiade OS, Ojezele OM, Ojezele JO, Ajayi AY (2012) Hypoglycaemic activity of Commelina africana and Ageratum conyzoides in relation to their mineral composition. Afr Health Sci 12: 198-203.

90. Sharma AK, Bharti S, Kumar R, Krishnamurthy B, Bhatia J, et al. (2012) Syzygium cumini ameliorates insulin resistance and $\hat{I}^{2}$-cell dysfunction via modulation of PPAR, dyslipidemia, oxidative stress, and TNF-Î \pm in type 2 diabetic rats. J Pharmacol Sci 119: 205-213.

91. Poongothai K, Ponmurugan P, Ahmed KS, Kumar BS, Sheriff SA (2011) Antihyperglycemic and antioxidant effects of Solanum xanthocarpum leaves (field grown \& in vitro raised) extracts on alloxan induced diabetic rats. Asian Pac J Trop Med 4: 778-785
92. Nyarko AK, Asare-Anane H, Ofosuhene M, Addy ME, Teye K, et al. (2002) Aqueous extract of Ocimum canum decreases levels of fasting blood glucose and free radicals and increases antiatherogenic lipid levels in mice. Vascu Pharmacol 39: 273-279.

93. Patel MB, Mishra SH (2011) Hypoglycemic activity of C-glycosyl flavonoid from Enicostemma hyssopifolium. Pharm Biol 49: 383-391.

94. Khosla P, Bhanwra S, Singh J, Seth S, Srivastava RK (2000) A study of hypoglycaemic effects of Azadirachta indica (Neem) in normaland alloxan diabetic rabbits. Indian J Physiol Pharmacol 44: 69-74.

95. Al-Shamaony L, al-Khazraji SM, Twaij HA (1994) Hypoglycaemic effect of Artemisia herba alba. II. Effect of a valuable extract on some blood parameters in diabetic animals. J Ethnopharmacol 43: 167-171.

96. Bavarva JH, Narasimhacharya AV (2008) Antihyperglycemic and hypolipidemic effects of Costus speciosus in alloxan induced diabetic rats. Phytother Res 22 620-626.

97. Yang XB, Huang ZM, Cao WB, Zheng M, Chen HY, et al. (2000) Antidiabetic effect of Oenanthe javanica flavone. Acta Pharmacol Sin 21: 239-242.

98. Al-Romaiyan A, Liu B, Asare-Anane H, Maity CR, Chatterjee SK, et al. (2010) A novel Gymnema sylvestre extract stimulates insulin secretion from human islets in vivo and in vitro. Phytother Res 24: 1370-1376.

99. Baskaran K, Kizar Ahamath B, Radha Shanmugasundaram K, Shanmugasundaram ER (1990) Antidiabetic effect of a leaf extract from Gymnema sylvestre in non-insulin-dependent diabetes mellitus patients. J Ethnopharmacol 30: 295300

100. Gupta R, Mathur M, Bajaj VK, Katariya P, Yadav S, et al. (2012) Evaluation of antidiabetic and antioxidant activity of Moringa oleifera in experimental diabetes. J Diabetes 4: 164-171.

101. Aftab S (2004) Aftab Saeed, Simple and Compound drugs. Pharmacopoeia 1: $2-400$ 